\title{
Stem cell therapy in diabetic foot patients: where are we now?
}

\author{
Stanley Kirana, Diethelm Tschöpe, Bernd Stratmann \\ Diabetes Center, Heart and Diabetes Center NRW,University Clinic of Ruhr University Bochum; Bad Oeynhausen, Germany
}

\begin{abstract}
Abstrak
Kaki Diabetik (KD) merupakan penyakit penyerta Diabetes Mellitus (DM). DM merupakan salah satu penyebab utama kasus amputasi non-traumatik di Jerman, dengan penyakit arterial perifer berat (PAP) dengan iskemia kritis tungkai yang menjadi masalah utama. Meskipun teknik modern tersedia, intervensi perkutan dan pembedahan pemulih vaskularisasi masih terbatas. Masalah ini menyebabkan peningkatan jumlah amputasi pada pasien dengan diabetes mellitus. Proses fisiologik angiogenesis, vaskulogenesis dan arteriogenesis mengarahkan ke pertumbuhan pembuluh darah kolateral pada keadaan penyakit penyumbatan pembuluh arterial penyebab iskemia tungkai. Pada praktik klinik respons angiogenik endogenik seringkali terganggu. Angiogenesis terapetik merupakan penerapan bioteknologi untuk merangsang pembentukkan pembuluh darah baru via (melalui) aplikasi lokal faktor penumbuh pro-angiogenik dalam bentuk protein rekombinan, atau terapi gen; atau dengan implantasi sel progenitor atau sel punca yang akan mensintesa sitokin angiogenik multipel. Artikel review ini merangkum fungsi endotelial dan disfungsi pada DM, mekanisme homing, metode transplantasi dan status uji klinik di bidang sel punca untuk pengobatan iskemia tungkai. (Med J Indones 2011; 20:154-60)
\end{abstract}

\begin{abstract}
Diabetic foot (DF) occurs as a concomitant illness of diabetes mellitus (DM). DM is one of the main causes of nontraumatic amputation in Germany with severe peripheral arterial disease (PAD) with critical limb ischemia (CLI) being of major concern. Although modern techniques are available surgical vascularisation and percutaneous intervention are limited. This problem leads increasing numbers of limb amputations in patients with diabetes mellitus. Thephysiological process of angiogenesis, vasculogenes is and arteriogenesis contribute to the growth of collateral vessels in response to obstructive arterial disease causing limb ischemi. In clinical practice the endogenous angiogenic response is often impaired. Therapeutic angiogenesis is an application of biotechnology to stimulate new vessel formation via local administration of pro-angiogenic growth factors in the form of recombinant protein, or gene therapy,or by implantation of progenitor cells or stem cells that will synthe size multiple angiogenic cytokines. This review summarises the endothelial function and dysfunctionin DM, the mechanism of homing, the transplantation method and the status of clinical trials in stem cell field to treat limb ischemia. (Med J Indones 2011; 20:154-60)
\end{abstract}

Key words: diabetes mellitus, endothelial progenitor cells, peripheral arterial disease, stem cells, therapeutic angiogenesis

Diabetes mellitus (DM) is known as an emerging chronic disease world wide. DM is accepted as cardiovascular risk factor and therefore plays an important role in the pathogenesis of cardiovascular disease. Peripheral artery disease (PAD) is one of the major health problems resulting from macrovascular complication in diabetic patients. As a manifestation of atherosclerosis, PAD is characterized by atherosclerotic occlusive disease of the lower extremities and is a marker for atherothrombotic disease in other vascular beds. PAD is present in approximately one-half of all patients with foot ulcers..$^{1-4}$ Along with polyneuropathy, PAD causes foot ulceration which often leads to lower limb amputations.

DM causes almost $50 \%$ of all non traumatic lowerextremity amputations world wide. It is estimated that the life time risk for amputation in diabetic patients is $10-15 \%$, which is $10-30$ times higher in comparison to the general population. ${ }^{5-8}$ In Germany the number of limb amputation is increasing. According to the newest data from German Association of Angiology, which were released during the Scientific Meeting in Mannheim in September 2008, about 60.000 amputations are performed every year. Compared to european countries such as Denmark and The Netherlands, Germany is leader in the number of limb amputation. The main factors inducing these amputations are diabetic foot (DF) or arteriosclerosis. Almost every $3^{\text {rd }}$ patient suffers from diabetes mellitus. An amputation for elderly patients resembles a fatal step in their quality of life.

In the other hand, the patients are often late to seek specialized professional care or they are not treated in a vascular center. These factors along with pathology-anatomical factors limit the possibilities for revascularisation.

The strengths and limitations of surgical revascularisation in PAD are well known. Surgical revascularisation and percutaneous interventions are limited to patients with critical limb ischemia (CLI) and those with disabling claudication (Fontaine Stadium IIb-IV) due to discrete proximal disease. ${ }^{1,9}$

\section{Endothelial functions and dysfunctions}

As key elements in the maintenance of tissue homeostasis, blood vessels serve as the conduits of circulation, transporting nutrients and oxygen to organs and tissues, and removing destructive catabolites and xenobiotics from the blood flow. ${ }^{10}$ 
For a long time two specialized endothelial functions were accepted: gas exchange in pulmonary circulation and fenestration in hepatic and splenic circulation. Under normal homeostatic conditions, the endothelium resists vasospasm, prevents leukocyte and platelet adhesion to the vessel wall, favours fibrinolysis, combats coagulation of blood, and inhibits the proliferation of vasculars mooth muscle cells.

During the last two decades, accumulating evidence has described the vascular endothelium as an active endocrine, paracrine, and autocrine organ, indispensable for the maintenance of vascular homeostasis. Altered homeostasis induced by various stimuli may cause localized alterations, or 'endothelial dysfunction', of the antihemostatic properties, vascular tone, heightened leukocyte adhesion, and increased production of cytokines and growth factors. The dramatic change of endothelial interactions with blood leukocyte soccurring in inflammation provides an example of endothelial activation. $^{10,12,13}$

\section{Diabetes mellitus and endothelial dysfunction}

Vascular diseases, including atherosclerosis, medial calcification, and microangiopathy, are prevalent in patients with DM and are the principal causes of morbidity and mortality in these individuals. Atherosclerosis occurs earlier in patients with diabetes, frequently with greater severity and more diffuse distribution.

Hyperglycemia per se causes endothelial dysfunction. Healthy humans exposed to a hyperglycaemic clamp sufficient to increase forearm glucose concentration experience impaired endothelium-dependent vasodilation. ${ }^{10,14,15}$ Hyperglycemia also decreases flowmediated endothelium-dependent vasodilation of the brachial artery of healthy subjects. ${ }^{14,16,17}$ Hyperglycemia may decrease the bioavailability of nitric oxide (NO) through multiple mechanisms (Figure1). Additionally, hyperglycemia may increase the formation of oxygen-derived free radicals that inactivate NO or cause intracellular signalling disturbances that inhibit nitric oxide synthase (NOS) activity and thereby reduce NO production. Hyperglycemia is also associated with increased oxidative stress. Increased inactivation of NO by oxygen-derived free radicals and decreased production of NO by NOS reduce NO levels in the vascular milieu. ${ }^{14,17-20}$

\section{Rationale for stem cell therapy in diabetic foot}

The essential part of normal wound healing is the formation of new blood vessels with in the provisional wound matrix that is referred to as granulation tissue. Neovascularisation of the granulation tissue occurs by the processes of angiogenesis or vasculogenesis, or both. $^{21,22}$ Therapeutic angiogenesis has been studied many times for the treatment of patients with peripheral arterial occlusive disease who do not qualify for surgical revascularisation or radiologic intervention. Angiogenesis can be achieved by introducing growth factors as mature proteins or as complementary DNA carrying vector systems (cDNA-plasmid) or stem cells which contain endothelial progenitor cells (EPCs) and mesenchymal cells. ${ }^{23-27}$

The following sections discuss various methods of using stem cell therapies to induce angiogenesis in DF.

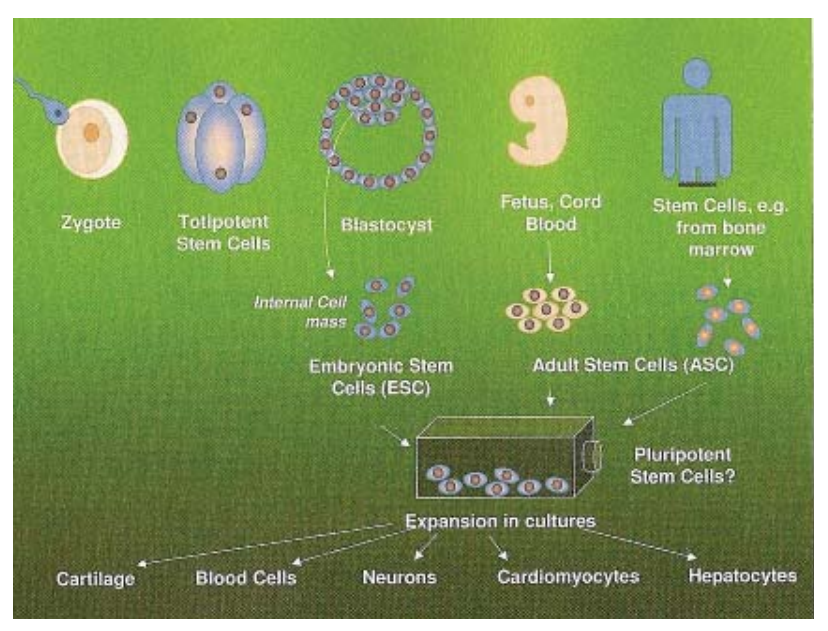

Figure 1. Sources for embryonic and adult stem cells ${ }^{28}$

\section{Definition of stem cells}

All life forms begin with a stem cell, which is defined as a cell that has the dual ability to self-renew and to produce progenitors and different types of specialized cells in the organism. ${ }^{28}$

Regardless of their sources, stem cells are defined by their indefinite capability of self-renewal (proliferation) and unlimited potential to generate specialized tissue cells (differentiation) (Figure2). Currently, scientists and clinical researchers are working on two major types of stem cells, embryonic and adult, which share three characteristic properties: 1 . Stem cells are premature, undifferentiated, or unspecialized. However, unspecialized stem cells can generate specialized cells, including heart muscle, blood vessels, blood cells, or nerve cells. 2. Stem cells can divide and renew themselves for long periods. Unlike other cells-which normally do not replicate by themselves-stem cells may replicate, or proliferate, many times. 3. Stem cells can respond to exogenous or endogenous signals by generating specialized cell types. When unspecialized stem cells develop into specialized cell, the process is called differentiation. ${ }^{29}$ 


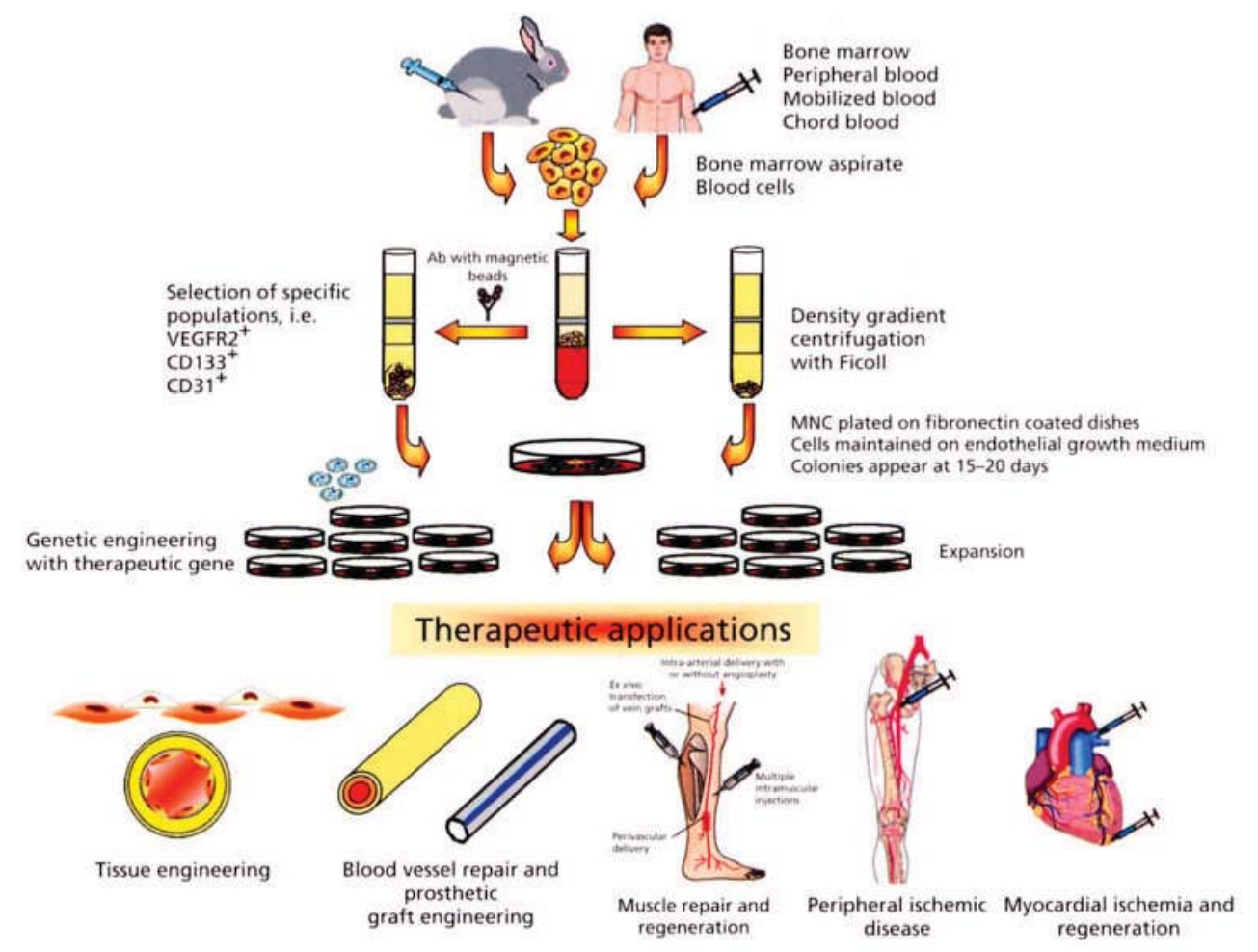

Figure 2. Isolation, cultivation and genetic engineering of endothelial progenitor cells (EPCs) for therapeutic application. EPC scan be isolated from the BM-MNC, peripheral blood or umbilical chord blood with or without further selection and purification.The mononuclear cells are expanded ex vivo under endothelialspecific growth conditions and may be genetically modified to over express one or several therapeutic genes.The differentiated cells are then used in transplantation protocols for rescue and repair of damaged tissue such as infarcted myocardium, ischemic limb or injured muscle. The cells may also be used for endothelialisation of damaged blood vessels and vascular prosthetic grafts and in tissue engineering. (Melo LG, Pachori AS, Kong D et al. Endothelium-targeted gene and cell-based therapy for cardiovascular disease. In: De Caterina R, Libby P, eds. Endothelial Dysfunctions and Vascular Disease. Oxford: Blackwell Futura; 2007:385)

\section{Adult and embryonic stem cells}

Human embryonic stem cells (ESCs) used for research have been extracted from embryos created by in vitro fertilization done by the group of James Thomson in 1998 and they reported on the etablishment of human ESC lines. They concluded that the ESCs have potential to form most cell types of the adult body over almost unlimited periods. ${ }^{28,30-32}$

The adult body has a small number of adult or somatic stem cells in some tissues and organs. Such adult stem cells (ASCs) have been known to posses the ability to regenerate the corresponding tissue from which they are derived. Hematopoietic stem cells (HSCs), for example, continuously regenerate the circulating blood cells and cells of the immune system during the life span of the organism. Based on animal studies, many researchers have recently claimed that ASCs might exhibit developmental potentials comparable to those exhibited by ESCs. ASCs have the ability to regenerate the tissue from which they are derived over the life span of the individual, while ESCs have the potential to form most cell types of the adult body over very long periods of in vitro cultivation. ${ }^{28,29,32-38}$ However, until now the use of human ESCs for research is prohibited in Germany. Many clinical research centers in Germany are focusing to develop the potential of ASCs.

\section{Endothelial progenitor cells for cardiovascular re- generation}

The differentiation of mesodermal cells to angioblasts and subsequent endothelial differentiation was believed to occur exclusively in embryonic development. Asahara et al. reported that purified CD34+ hematopoietic progenitor cells from adults can differentiate ex vivo to an endothelial phenotype. ${ }^{40,41}$ These cells were named "endothelial progenitor cells" (EPC). Shi et al. reported in 1998 the existence of "circulating bone marrowderived endothelial progenitor cells' (CEPC). ${ }^{58}$ This is actually a similar finding to Asahara. EPC or CEPC were defined as cells, which express both, hematopoietic stem cell markers such as CD34 and an endothelial marker protein such as the VEGF-receptor KDR. 
CD34 is not expressed exclusively on hematopoietic stem cells (HSC) but also on mature endothelial cells. Further studies used the more immature HSC marker CD133 also known as prominin or AC 133. Purified isolated CD $133^{+}$cells also differentiated to endothelial cells in vitro. ${ }^{41,42}$ However, the biological function of CD133 remains unclear. It is not well known whether CD133 only represents a surface marker or has a functional activity involved in regulation of neovascularisation. ${ }^{41}$

The characterization of EPC becomes particularly difficult when cells are expanded and cultured ex vivo, since the culture conditions (culture supplements such as fetal calf serum and cytokines or different plastic types) rapidly change the phenotype of the cells. Moreover, continuous cultivation was shown to increase endothelial differentiation, as evidenced by elevated endothelial marker protein expression.

Smooth muscle cells (SMC) and endothelium are two essential structures for the architecture of the blood vessels. Vascular stem cells, a group of multipotent heterogenous stem cells, largely fall into two subgroups: endothelial and SMC progenitors. EPC develop closely from $\mathrm{CD}_{3} 4^{+}$to bone marrow stem cells, in particular those committed to the monomyeloid cell lineage, whereas SMC progenitors may belong or originate together in mesenchymal stem cells (MSC), which are negative for CD34. Atherosclerosis causes arterial wall damage and impairs the capacity of both vascular stem cell types to regenerate neovascular tissue, or may trigger abnormal proliferation or death by apoptosis under different pathological conditions. ${ }^{29}$

\section{Mechanism of vessel formation}

Angiogenesis is defined as the sprouting of new capillaries from existing vascular structure, a process that is triggered by endothelial cell migration and proliferation. Remodelling of the extra cellular matrix (ECM), tubule formation and expansion of the surrounding vascular tissue are key elements of angiogenesis.

The in situ formation of new blood vessels from ECP which differentiated into endothelial cells and fuse into luminal structures is called vasculogenesis.

Meanwhile, arteriogenesis refers to an increase in the calibre of pre-existing arteriolar collateral connections by recruitment of perivascular cells and expansion and remodelling of the extracellular matrix. Arteriogenesis increases the size and wall thickness of collateral vessels, and shear stress (rather than hypoxia) seems to be the main factor that stimulates arteriogenesis. ${ }^{9}$

The key steps in vessel formation-namely endothelial cell activation, migration, proliferation and reorgani- sation- are tightly regulated in a complex balance between pro-and anti-angiogenic mechanisms (Table1). ${ }^{9}$

Table 1. Factors that stimulate and inhibit angiogenesis

\begin{tabular}{ll}
\hline Stimulators & Inhibitors \\
\hline VEGF & Angiostatin \\
aFGF & Thrombospondin \\
bFGF & Endostatin \\
PDGF & Troponin-I \\
TGF $\alpha / \beta$ & TIMPs \\
TNF $\alpha$ & Suramin \\
HGF & \\
Angiogenin & \\
PIGF & \\
Angiopoietin & \\
Oestrogen & \\
Nitric oxide & \\
\hline
\end{tabular}

VEGF: vascular endothelial growth factor; aFGF, bFGF: acid and basic fibroblast growth factor (FGF-1 and-2, respectively); PDGF: platelet-derived growth factor; TGF: transforming growth factor; TNF: tumour necrosis factor; HGF: hepatocyte growth factor; PIGF: placental growth factor; TIMPs: tissue inhibitors of metalloproteinases.

The most important pro-angiogenic factors are vascular endothelial growth factor (VEGF) and basic fibroblast growth factor (bFGF), also known as FGF-2. VEGF is an endothelial cell specific mitogen that is markedly upregulated by hypoxia, and plays an important role in endothelial cell proliferation, differentiation and survival.

FGFs are non-secreted growth factors that are released only during cell death or ischemic cell injury. Clinical and biochemical factors also influence the formation of, and biological response to different angiogenic growth factors. Hypoxia, for example, is the most potent inducer of angiogenesis, ${ }^{44}$ principally via up-regulation of VEGF, whereas diabetes mellitus and increased levels of cholesterol and lipoprotein(a) are associated with a reduced angiogenic response. ${ }^{9}$

As bone marrow-derived stem and progenitor cells home to sites of ischemia, this may allow the local release of factors acting in paracrine manner on the surrounding ischemic tissue. Bone marrow-derived mononuclear cells release angiogenic growth factors such as VEGF, bFGF and angiopoietins, thereby enhancing the local angiogenic response., ${ }^{9,41,44}$ This mechanism is named 'homing' and it is the most likely theory which represents the reality in ischemic process.

During tissue injury, e.g. wound, the formation of new blood vessels is needed. Neovascularization of the wound's granulation tissue occurs by the processes mentioned above. However, in diabetic patients these angiogenic mechanisms are reduced. 
The idea to induce neovascularisation in the wound area or ischemic area is now a hot topic in regenerative medicine. There are a lot of clinical trials in this area, however only few centers world wide perform these studies.

\section{Stem cell transplantation}

Until now, there are a lot of protocols, hypotheses, debates and discussions about the best methods of stem cell transplantation. Most clinical studies are performing 2 methods of stem cell transplantation: intra-arterial and intra-muscular.

The concept of intra-arterial stem cell transplantation assures that the stem cells reach all stenosis sites antegradely. We believe that the stenosis area is the ischemic area which stimulates the homing effect of the cells. The intra-muscular application is based on the ischemic musculature which could be supplied with a high concentration of stem cells through several local depots. Whether the cells reached the ischemic area by blood flow remains unclear. In theory, it induces the homing effect and then stimulates the angiogenesis or vasculogenesis in the ischemic area. ${ }^{45-47}$

\section{Current clinical trial}

There are a lot of clinical trials running on this topic (Table 2). However, the outcomes have not been published yet. Only some studies published their results or case reports. ${ }^{25,45,46} \mathrm{~A}$ multi center study has not been performed to take conclusion of stem cell therapy. To what we know, the data from other centers as well as ours show positive results (Figure 3 ).

Table 2. List of stem cell clinical trials in critical limb ischemia as listed in Clinicaltrial.gov from September 2007

\begin{tabular}{|c|c|c|}
\hline Location & Status & Trial name \\
\hline USA & Recruiting & ALDHbr Cells for Critical Limb Ischemia \\
\hline USA & Recruiting & Safety Study of Using Stem Cells to Stimulate Development of New Blood Vessels in Peripheral Vascular Disease \\
\hline USA & Recruiting & Combination Stem Cell Therapy for the Treatment of Severe Leg Ischemia \\
\hline USA & Recruiting & $\begin{array}{l}\text { Vascular Repair Cells (VRC) Treatment of Patients With Peripheral Arterial Disease Related Critical Limb Ischemia } \\
\text { (RESTORE-CLI) }\end{array}$ \\
\hline USA & Recruiting & Study of Autologous Bone Marrow Concentrate for theTreatment of CLI \\
\hline USA & Recruiting & StemCells for Treating Critical Ischemia \\
\hline Japan & Recruiting & Stem Cell Study for Patients With Leg Ulcer / Gangrene \\
\hline Japan & Recruiting & TACT-NAGOYA: Therapeutic Angiogenesis Using Cell Transplantation \\
\hline Korea & Recruiting & $\begin{array}{l}\text { Study for Safety and Efficiency of Therapeutic Angiogenesis for Patients With Limb Ischemia by Transplantation of } \\
\text { Human Cord Blood Mononuclear Cell }\end{array}$ \\
\hline The Netherlands & Recruiting & Intra-Arterial Stem Cell Therapy for Patients With Chronic Limb Ischemia (CLI) \\
\hline The Netherlands & Recruiting & Autologous Bone Marrow-Derived Mononuclear Cells for Therapeutic Arteriogenesis in Patients With Limb Ischemia \\
\hline Italy & Recruiting & AutologousBone Marrow Cell Treatment in Peripheral Atherosclerosis \\
\hline France & Recruiting & Cell Therapy in Chronic Limb Ischemia \\
\hline Denmark & Recruiting & Treatment of Severe Limb Ischemia With Autologous Bone Marrow Derived Mononuclear Cells \\
\hline Germany & Finished & Novel Therapy of PAD by Combined Transplantation of BMCs (TAM-PAD) \\
\hline Germany & Recruiting & Autologous Bone Marrow Transplantation for Critical Limb-Threatening Ischemia \\
\hline
\end{tabular}

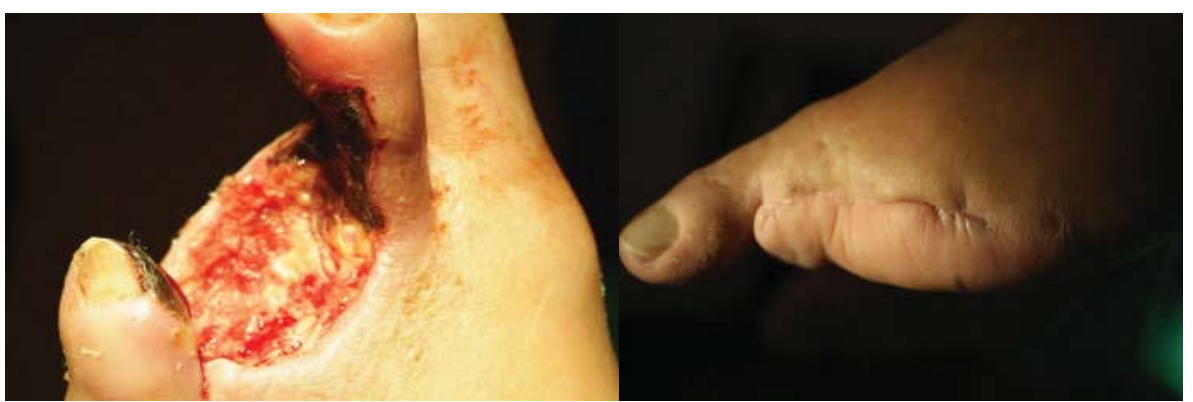

Figure 3. Bone marrow stem cell therapy in diabetic foot (Bad Oeynhausen Working Group, Germany). This patient had a chronic limb ischemia with forefoot necrosis. Distal stenosis A. tibialis anterior and A. dorsalis pedis without collateralisation was verified by angiography. Discussion between vascular surgeon, intervention angiologist and internist revealed no surgical or interventional therapeutic option. Due to the stenosis location and vascular structure, no possibilities to perform bypass or other intervention were seen. The patient agreed with the autologous bone marrow stem cell therapy.

Left picture shows the wound status before intra muscular stem cell transplantation. Right picture shows the complete wound healing 20 weeks after stem cell transplantation. Small calibre new vessel formation was proved by angiography. (With permission from Kirana, Stratmann et al. Wound therapy with autologous bone marrow stem cells in diabetic patients with ischaemia- induced tissue ulcers affecting the lower limbs. Int J Clin Pract 2007;61:690-2) 
In conclusion, bone marrow derived EPCs are the newest cellular target that may be used to influence postnatal neovascularisation. The formation of new blood vessels, including collaterals, is a complex physiological process that occurs in adults in response to tissue injury or ischemia.

The stem cell transplantation to induce vessel formation is promising and could be a new therapeutic option in the future to treat limb ischemia without options of revascularization. However, there is still much to learn about the optimum treatment modality, dosing frequency and route of administration, especially in patients with diabetes mellitus. We know that these patients have a reduced capability of vascular self-renewing.

Until now, there are only some reports and clinical trials which have already been finished with the whole evaluations and they show an improvement of blood perfusion in ischemic area. Moreover, multicenter studies with large numbers of patients are expected to give more information about stem cell therapy.

\section{Acknowledgments}

The Bad Oeynhausen stem cell trial was supported by Aastrom Bioscience Inc., Ann Arbor-USA. We thank Dr. E. Danch of the Vascular Surgery, Bad Oeynhausen General Hospital, Germany for his critical opinion of patient recruitment. We also thank all colleagues in Diabetes Center NRW, Bad Oeynhausen for helping us in patient recruitment and performing diagnostic.

\section{REFERENCES}

1. American Diabetes Association Editors. Peripheral Arterial Disease in People with Diabetes: Consensus Statement. Diabetes Care 2003; 26:12: 3333-41.

2. Prompers L, Schaper J, Apelqvist J et al. Prediction of outcome in individuals with diabetic foot ulcers: focus on the differences between individuals with and without peripheral arterial disease. The EURODIAL Study. Diabetologia 2008; 51:747-755.

3. Prompers L, Huijberts M, Apelqvist J et al. High prevalence of ischaemia, infection and serious comorbidity in patient with diabetic foot disease in Europe. Baseline results from the Eurodiale Study. Diabetologia 2007; 50: 18-25.

4. Boulton AJ. The pathogenesis of diabetic foot problems: an overview. Diabet Med 13 (Suppl1): S12-S16.

5. Tentolouris N, Al-Sabbagh S, Walker MG et al. Mortality in diabetic and nondiabetic patients after amputation performed from 1990 to 1995. Diabetes Care 2004; 27: 1598-604.

6. Most RS, Sinnock P. The epidemiology of lower extremity amputations in diabetic individuals. Diabetes Care 1983; 6: 87-91.

7. Siitonen OI, Niskanen LK, Laakso M et al. Lower extremity amputations in diabetic and non diabetic patients: a population-based study in eastern Finland. Diabetes Care 1993; 16:16-20.
8. Chaturvedi N, Stevens LK, Fuller JH et al. Risk factors, ethnic differences und mortality associated with lower extremity gangrene and amputation in diabetes: the WHO multinational study of vascular disease in diabetes. Diabetologia 2001; 44 (Suppl.2) 27:7:S65-S71.

9. Collinson DF, Donnelly R. Therapeutic angiogenesis in peripheral arterial disease: can biotechnology produce an effective collateral circulation? Eur J Vasc Endovasc Surg 2004; 28:9-23.

10. De Caterina R, Massaro M, Libby P. Endothelial function and dysfunctions. In: De Caterina R, Libby P, eds. Endothelial Dysfunctions and Vascular Disease. Oxford: Blackwell Futura; 2007: 1-25.

11. Fishman AP. Endothelium: a distributed organ of diverse capabilities. Ann NY Acad Sci 1982; 401: 1-8.

12. Gimbrone MA, Kume N, Cybulsky MI. Vascular endothelium dysfunction and the pathogenesis of atherosclerosis. In: Weber PC, Leaf A, eds. Atherosclerosis Reviews. NewYork: Raven Press; 1993.

13. De Caterina R, Libby P, Peng HB et al. Nitric oxide decreases cytokine-induced endothelial activation. J Clin Invest 1995; 96: 60-8.

14. Creager MA, Beckman JA. Vascular function and diabetes mellitus. In: De Caterina R, Libby P, eds. Endothelial Dysfunctions and Vascular Disease. Oxford: Blackwell Futura; 2007:232-44.

15. Williams SB, Goldfine AB, Timimi FK et al. Acute hyperglycemia attenuates endothelium-dependent vasodilation in humans in vivo. Circulation 1998; 97: 1695-701.

16. Kawano H, Motoyama T, Hirashima O et al. Hyperglycemia rapidly suppresses flow-mediated endothelium-dependent vasodilation of brachial artery. J Am Coll Cardiol 1999; 34: 146-54.

17. Uribarri J, Stirban A, Sander D, et al. Single oral challenge by advanced glycation end products acutely impairs endothelial function in diabetic and non diabetic subjects. Diabetes Care. 2007; 30(10): 2579-82.

18. HinkU, LiH, Mollnau H et al. Mechanisms underlying endothelial dysfunction in diabetes mellitus. Circ Res 2001; 88: E14-E22.

19. Brownlee M. Biochemistry and molecular cell biology of diabetic complications. Nature 2000; 404: 787-90.

20. Nishikawa T, Edelstein D, Du XL et al. Normalizing mitocondrial superoxide production blocks three pathways of hyperglycaemic damage. Nature 2000; 404: 787-90.

21. Velazquez OC. Angiogenesis and vasculogenesis: Inducing the growth of new blood vessels and wound healing by stimulation of bone marrow-derived progenitor cells mobilization and homing. J Vasc Surg 2007; 45: 39A-47A.

22. Bauer SM, Bauer RJ, Velasquez OC. Angiogenesis, vasculogenesis, and induction of healing in chronic wounds. Vasc Endovascular Surg 2005; 39: 293-306.

23. Ausprunk DH, Folkman J. Migration and proliferation of endothelial cells in performed and newly formed blood vessels during tumor angiogenesis. Microvasc Res 1977;14: 53-65.

24. Kim D-I, Kim M-J, Joh J-H et al. Angiogenesis Facilitated by Autologous Whole Bone Marrow Stem Cell Transplantation for Buerger's Disease. Stem Cells 2006; 24(5): 1194-200.

25. Tateishi-Yuyama E, Matsubara H, Murohara T et al. Therapeutic angiogenesis for patients with limb ischaemia by autologous transplantation of bone-marrow cells: a pilot study and a randomised controlled trial. Lancet 2002; 360:427-35

26. Nikol S. Therapeutic angiogenesis for peripheral artery disease: Genetherapy. VASA 2007; 36:165-73. 
27. Asahara T, Kalka C, Isner JM. Stem cell therapy and gene transfer for regeneration. Gene Ther 2000;7(6):451-7.

28. Ho AD, Wagner W. Clinical Potentials of Stem Cells: Hype or Hope? In: Ho AD, Hoffman R, Zanjani ED, eds. Stem Cell Transplantation Biology, Processing, and Therapy. Weinheim: Wiley-Vch; 2006:3-25.

29. Geng YJ, Madonna R. Stem cells in atherosclerosis and atherosclerosis-related vascular disorder. In: De Caterina R, Libby P, eds. Endothelial Dysfunctions and Vascular Disease. Oxford: Blackwell Futura; 2007:350-64.

30. Thomson JA, Itskovitz-Eldor J, Shapiro SS, Waknitz MA, Swiergiel JJ, Marshall VS et al. Embryonic stem cell lines derived from human blastocysts. Science 1998; 282: 1145-47.

31. Richards M, Fong CY, Chan WK, Wong PC, Bongso A. Human feeders support prolonged undifferentiated growth of human inner cell masses and embryonic stem cells. Nat Biotechnol 2002;20:933-6.

32. Gage FH. Mammalian neural stem cells. Science 2000; 287 : 837-45.

33. Weissmann IL. Translating stem and progenitor cell biology to the clinic: barriers and opportunities. Science 2000; 287:1442-6.

34. Ho AD, Punzel M. Hematopoietic stem cells: can old cells learn new tricks? J Leucocyte Biol 2003; 73:547-55.

35. Wagers AJ, Christensen JL, Weissmann IL. Cell fate determination from stem cells. Gene Ther 2002;9:606-12.

36. Terada N, Hamazaki T, Oka M et al. Bone marrow cells adopt the phenotype of other cells by spontaneous cell fusion. Nature 2002; 416: 542-5.

37. Ying QL, Nichols J, Evans EP et al. Changing potency by spontaneous fusion. Nature 2002; 416: 545-8.

38. Morshead CM, Benveniste P, Iscove NN et al. Hematopoietic competence is a rare property of neural stem cells that may depend on genetic and epigenetic alterations. Nat Med 2002;8: 268-73

39. Amit M, Shariki C, Margulets V et al. Feederlayer and serum free culture of human embryonic stem cells. Biol Reprod 2004;70:837-45.

40. Asahara T, Murohara T, Sullivan A et al. Isolation of putative progenitor endothelial cells for angiogenesis. Science 1997;275(5302):964-7.

41. Fischer-Rasokat U, Dimmeler S. Endothelial Progenitor Cells for Cardiac Regeneration. In: Ho AD, Hoffman R, Zanjani ED, eds. Stem Cell Transplantation Biology, Processing, and Therapy. Weinheim: Wiley-Vch; 2006:3-25.

42. Gehling UM, Ergün S, Schumacher U et al. In vitro differentiation of endothelial cells from AC133-positive progenitor cells. Blood 2000;95(10):3106-12.

43. Fujiyama S, Amano K, Uehira K et al. Bone marrow monocyte lineage cells adhere on injured endothelium in a monocyte chemoattractant protein-1-dependent manner and accelerate reendothelialization as endothelial progenitor cells. Circ Res. 2003; 93(10):980-9.
44. Giordano F, Johnson RS. Angiogenesis: the role of the microenvironment in flipping the switch. Curr Opin Genet Dev 2001;11:35-40.

45. Bartsch T, Brehm M, Zeus T et al. Transplantation of autologous mononuclear bone marrow stem cells in patients with peripheral arterial disease (The TAM-PAD study). Clin Res Cardiol 2007; 96(12):891-9.

46. Kirana S, Stratmann B, Lammers D et al. Wound therapy with autologous bone marrow stem cells in diabetic patients with ischaemia-induced tissue ulcers affecting the lower limbs. Int J Clin Pract 2007;61(4):690-2.

47. Gastens MH, Goltry K, Prohaska W et al. Good manufacturing practice-compliant expansion of marrow-derived stem and progenitor cells for cell therapy. Cell Transplant. 2007;16(7):685-96.

48. Oswald J, Boxberger S, Jorgensen B, Feldmann S, Ehninger $\mathrm{G}$, Bornhauser $\mathrm{M}$ et al. Mesenchymal stem cells can be differentiated into endothelial cells in vitro. Stem Cells 2004;22(3):377-84.

49. Prante C, Bieback K, Funke C, Schon S, Kern S, Kuhn J et al. The formation of extracellular matrix during chondrogenic differentiation of mesenchymal stem cells correlates with increased levels of xylosyltransferase I. Stem Cells 2006.

50. Huang P, LiS, Han M et al. Autologous Transplantation of Granulocyte Colony-Stimulating Factor-Mobilized Peripheral Blood Mononuclear Cells Improves Critical Limb Ischemia in Diabetes. Diabetes Care 2005;28:2155-60.

51. Rodriguez L, Azqueta C, Azzalin S, Garcia J, Querol S. Washing of cord blood grafts after thawing: high cell recovery using an automated and closed system. Vox Sang 2004; 87(3):165-172.

52. Mandalam RK, SmithAK. Ex vivo expansion of bone marrow and cord blood cells to produce stem and progenitor cells for hematopoietic reconstitution. Mil Med 2002;167(2 Suppl):78-81.

53. Schwartz RM, Palsson BO, Emerson SG. Rapid medium perfusion rate significantly increases the productivity and longevity of human bone marrow cultures. Proc Natl Acad Sci U S A 1991;88(15):6760-4.

54. Lemarie C, Calmels B, Malenfant C, Arneodo V, Blaise $\mathrm{D}$, Viret $\mathrm{F}$ et al. Clinical experience with the delivery of thawed and washed autologous blood cells, with an automated closed fluid management device: Cyto Mate. Transfusion 2005;45(5):737-42.

55. Norgren L, Hiatt WR, Dormandy JA. Inter-Society Consensus for the Management of Peripheral Arterial Disease (TASCII). J Vasc Surg 2007;45(Suppl)S:S5-67.

56. Selvin E, Marinopoulos S, Berkenblit G et al. Meta-analysis: glycosylated hemoglobin and cardiovascular disease in diabetes mellitus. Ann Intern Med 2004;141(6):421-31.

57. Muntner P, Wildman RP, Reynolds K et al. Relationship between $\mathrm{HbA} 1 \mathrm{c}$ level and peripheral arterial disease. Diabetes Care 2005;28(8):1981-7.

58. Shi Q, Rafii S, Wu MH et al. Evidence for circulating bonemarrow-derived endothelial cells. Blood 1998; 92:362-7. 